\title{
GLOBAL PRODUCTS OR CUSTOMIZATION TO DIFFERENT COUNTRIES: CONCEPTUAL FRAMEWORK AND APPLICATION AT WAHLER, A GERMAN COMPANY OF THE AUTOMOTIVE SECTOR
}

\author{
Ailton Conde Jussani \\ Doctorate Degree in Administration by the University of São Paulo \\ Researcher at the PROFUTURO/FIA-Future Studies Program \\ ailtoncj@uol.com.br

\section{Eduardo Pinheiro Gondim de Vasconcellos} \\ Doctorate Degree in Administration by the University of São Paulo \\ Titular Professor at the Economics, Administration and Accountabiliy Faculty, \\ University of São Paulo, Brazil \\ epgdvasc@gmail.com
}

\section{ABSTRACT}

Competition in global markets demands product strategies that can help firms deal with the dilemma of global products versus customization, in serving the markets of different countries. Global products lead to large scales, automation, lower costs, plus the easy transfer of people and technology among many subsidiaries, as well as between corporate headquarters and the subsidiaries. However, the lack of customization makes it difficult to gain share in countless market segments, in many countries, and it may even stop a firm from entering in certain countries. This study outlines a model designed to facilitate this type of decisionmaking. First, based on the literature, a conceptual model was drawn up and the decision-related elements were grouped into seven factors that aid product customization decisions: 1. Market Positioning; 2. Customers' strategic importance; 3. Product life-cycle development; 4. Legal requirements; 5. Physical environment; 6. Infrastructure and compatibility; and 7. Suppliers' strategic importance. The case method was used, given the complex nature of the problem, which calls for an indepth analysis. The model was tested on one of the products made a German company with a Brazilian subsidiary. The components of the valve and the technological trends were analyzed. The case study showed that the influencing factors are interrelated. It became clear that the 
technological component is directly related with the seven decision factors, and this aspect is analyzed in depth. Nevertheless, further studies are necessary to validate the model, since the case method does not allow one to generalize the findings.

Keywords: Company internationalization. Product development. Product customization. Technology.

\section{RESUMO}

A competição nos mercados globais exige estratégias de produto que podem ajudar as empresas a lidar com o dilema de produtos globais versus personalização ao servir aos mercados de diferentes países. Globais produtos levam a grandes escalas, automação, custos mais baixos, além da transferência fácil de pessoas e tecnologia entre muitas subsidiárias, bem como entre a sede e as filiais. No entanto, a falta de personalização torna difícil ganhar participação em inúmeros segmentos do mercado em muitos países e pode até mesmo impedir uma firma de entrar em certos países. Este estudo descreve um modelo projetado para facilitar este tipo de tomada de decisão. Em primeiro lugar, com base na literatura, um modelo conceitual foi elaborado e os elementos relacionados com tomada de decisão foram agrupados em sete fatores que auxiliam as decisões de personalização do produto: 1. Posicionamento no mercado; 2. Importância estratégica dos clientes; 3. Desenvolvimento de ciclo de vida do produto; 4. Requerimentos legais; 5. Física ambiental; 6. Infraestrutura e compatibilidade; e 7. Importância estratégica dos fornecedores. Foi utilizado o método de Estudo de Caso, dada a complexidade do problema, que exige uma análise aprofundada. O modelo foi testado em um dos produtos feitos com uma empresa alemã com uma subsidiária brasileira. Foram analisados os componentes da válvula e as tendências tecnológicas. O estudo de caso mostrou que os fatores influentes são interrelacionados. Tornou-se claro que o componente tecnológico está diretamente relacionado com os sete fatores de decisão e este aspecto é analisado em profundidade. No entanto, mais estudos são necessários para validar o 
modelo, desde que o método caso não permitam generalizar as conclusões.

Keywords: Internacionalização de empresas. Desenvolvimento de novos produtos. Customização de produtos. Tecnologia. 


\section{INTRODUCTION}

Within the global marketing scenario, companies need to adapt their management models, in order to meet the different demands for customization, in the international market, and foster the exchange of knowledge between the subsidiaries, with the corresponding balance between autonomy and integration. According to Kotler e Keller (2006), a company uses global marketing when it operates in several countries and benefits from its operation (research, production, logistics, finance and marketing), as regards cost levels and reputation, thus becoming significantly more competitive than its purely local competitors.

A critical aspect related with the marketing function is the balance between product standardization and product customization, for the different markets. The highest level of customization may result in the loss of synergies and scale, as well as in an unnecessary cost increase. On the other hand, the acceptance of the product by the target market may be unfeasible with the lowest level of customization, due to the customers' lack of interest (KEEGAN; GREEN, 1999).

Thus, the research problem is: which are the factors that influencing the decision to customize industrial products for a specific country, as regards the marketing function, in an international company?

Then, to answer the research problem, it was formulated the following general objective: identifying, within the marketing function at the internationalized company, the influencing factors related with the decisions on customizing industrial products for a specific country.

The relevance of this research is based on the difficulties found by companies to identify the appropriate level of product customization for the different countries. Furthermore, there is a lack of empirical studies that analyze the research problem as it has been proposed.

\section{CONCEPTUAL FRAMEWORK}

\subsection{Internationalization}

Presently, the world is in an era in which products are manufactured in one country and shipped to another, where they undergo additional processes to become finished products. Later, they may be stored and/or sold in different countries, often repaired or reused, recycled or discarded (FERDOWS, 1997). 
The theories around the internationalization process of companies may be divided in two distinct theoretical lines: economics theories and behavioral theories, as follows.

Based on the economics perspective of internationalization, Dunning (1994) presents one of the classic outlooks on the matter. In his opinion (Ibid), the search for resources, markets, efficiency and strategies abroad is what attracts the investment that warrants committing resources, which, in turn, drives the company to improve its financial performance. In this model, the idea of an explanation about international activities needs to be based on several economics theories. Direct foreign investment is one of the possibilities for the international involvement of companies. The firm would have competitive advantages by becoming international, positioning itself above its competitors.

Unlike Dunning (Ibid.), the approach taken by the behavioral theories (JOHANSON; VAHLNE, 1990), surpasses the limitations imposed by the economics aspects, in order to understand the processes of decision-making, associated with the internationalization of companies.

This approach is represented by the Uppsala model, according to which, a company's knowledge is accumulated through its involvement in international operations (Ibid., p. 11).

According to Hitt et al (2008, pg. 211) an international strategy is one by which the company sells its products or services outside its local market scenario. One of the main reasons for implementing an international strategy is the potential of the international markets to generate new opportunities. Another reason to enter international markets is to guarantee the resources that companies need for production purposes. Raw material inventories are important for some sectors (Ibid).

According to Porter (1980), competitive strategies are a company's offensive and defensive actions to create a sustainable position within its sector. This author (Ibid.) has identified three generic strategies that can be used, individually, or as a group, in order to generate a sustainable position for the long term: the Cost Leadership Strategy, the Differentiation Strategy and the Focus Strategy.

The level of international diversification that can be managed varies between companies, and it depends on each manager's abilities. Issues of coordination may be attenuated by diversifying activities to countries with geographic proximity and cultural similarities. 
Hitt et al (2008, pg. 232) have indicated that, by acting in this manner, the company will probably have fewer commercial obstacles, a greater comprehension of the legal framework and of local habits, as well as a faster acceptance of its products by the local markets.

\subsection{Product Strategies}

The planning of an international product involves decions on the following issues: which products will be introduced; in which markets; what customizations should be made; which products should be added and/or excluded; what should be the brands and packaging; and, which services should be made available to foreign consumers (PIPKIN, 2005).

As part of the discussion about export markets, Keegan and Green (1999, pg. 233) have stated that a product will be feasible for the international market if it meets the following criteria:

i. The product appeals to the consumers in the potential market;

ii. It does not have to be customized beyond that which is economically justifiable by the expected sales volume;

iii. Import restrictions do not exclude the product, nor do they make it unreasonably expensive for the target market;

iv. Shipping costs to the target market are compatible with competitive prices;

v. The cost of gathering information for sales, catalogues and technical materials is feasible, vis-à-vis the potential market.

\subsection{Decisions About Product Customization}

The term 'product' is defined broadly, and it includes physical goods, services, events, people, places, organizations, ideas or a combination of all these elements (KOTLER; ARMSTRONG, 2003).

Each type of product demands an appropriate strategy of marketing mix. There are other structures to classify products, as for example: durable goods, nondurable goods and dispensable items. These may, in turn, be classified on the basis of different criteria (cf. KEEGAN; MORIARTY; DUNCAN, 1995).

According to Kotler and Armstrong (2003), products have three levels:

i. The core product: these are the basic benefits of a product that solve the consumers' problem. This is what consumers seek when they acquire a product; 
ii. The basic product: this surrounds the core product, and it may present up to 5 characteristics, as for example, level of quality, characteristics, design, brand name and packaging;

iii. The extended product: this stems from the core and the basic product. It offers additional benefits to the consumer, as installation, extended warranty and after-sales services.

Based on the above definitions of products, the authors (Ibid.) indicate three strategies for products to be launched in foreign markets: 1 . Direct extension of the product. This means launching the product overseas without undergoing any changes. 2. Product customization. It involves changing the product to meet the local conditions or expectations. 3. Product creation. This is about creating something new for the overseas market.

On the other hand, Czinkota and Ronkainen (2001, pg. 306) present four alternatives to address international markets: 1 . Selling products as they are, in the international market; 2 . Modifying products for the different countries; 3 . Designing new products for foreign markets; 4 . Adding new features to a product and launching it as a global one.

According to Levitt (1983), selling the same product, in the same way, to all consumers means standardizing its production, distribution, marketing and management. Thus, companies with global products offer reliable, quality items at low prices. The authors cite the following ones as examples of global products: Coca Cola and McDonald's (LEVITT, 1983). An example of a global product in B2B marketing would be the Intel processors.

\subsection{Comparison: Product Standardization and Product Customization}

Many products are adapted to a certain extent (CATEORA; GRAHAM, 1999, pg. 334; JOHANSSON, 2006, passim), even those that are traditionally regarded as standardized goods. On the other hand, the fact that different products may be necessary to meet local needs does not necessarily mean that certain features of these products cannot be standardized.

Thus, as companies gain experience in global markets, the new approach is to standardize wherever possible, and adapt wherever necessary, in order to take maximum advantage of standardization, while, at the same time, offering a difference to meet local needs. A platform is then developed with the basic technology, and the variations to the platform are later included. (Ibid.) Chart 1 
has been adapted from Gati and Vasconcellos (2009), and it shows the main advantages in standardizing and customizing products for markets in different countries.

\section{Chart 1 - Advantages of product standardization and product customization}

\section{Advantages of Standardization}

1. It is geared towards lower costs through mass production.

2. It allows companies to use the same product in different units or countries with similar characteristics, thus enabling economies of scale and R\&D efforts.

3. It lowers the costs of purchases, production and inventory.

4. It reduces duplicating R\&D efforts.

5. It allows consumers to use familiar products when traveling overseas.

6. It permits entry into low cost markets by taking advantage of the production platforms.

7. A higher number of standardized components results in better quality, with the corresponding benefit for all countries using the product.

8. It facilitates international operations and global competition.

9. It standardizes other elements in the mix, with the corresponding savings in marketing, i.e. marketing strategies may be easily transferred between countries.

10. It allows the company to meet the needs of global consumers. Example: Usually, decisions regarding purchases and supplies are centralized or regionalized. Thus, these consumers demand products that are standardized around the world.

11. It shortens the sales time cycle. This means that by centralizing the research and development of new products in a few projects, companies are able to reduce the time necessary to take new products to market.

\section{Advantages of Customization}

1. It is geared towards increasing customer satisfaction by adapting the product to local needs.

2. It uses the equipment available at the local units, which reduces potential capital expenses.

3. Consumers in high-income countries tend to buy more sophisticated items. Customization is advantageous in that it develops differentiated products with extra components for these consumers.

4. It shortens the time needed to adjust the product to local customer preferences.

5. The company can take advantage of subsidies and other benefits offered by the local government. Example: Tax incentives for the production of low-cost automobiles increase the production of these models.

6. It avoids or reduces taxes to import components or final products.

7. It lowers potential costs in logistics related with importing materials and final products.

8. It projects an image of a company geared towards the local market, while it maintains the recognition and the value of the international brand.

9. It encourages innovation and creativity.

10. It uses patents as a barrier for the entry of new competitors.

11. It facilitates local marketing and local competition, i.e. cultural differences of consumers in international markets will have an impact on the decision regarding product customization.

12. It encourages the manufacturing of a core product. Example: Small differences, as more potent heaters for northern countries, or stronger air-conditioning systems for vehicles sold in southern Europe, can be easily customized.

SOURCE: Adapted from GATI; VASCONCELLOS, 2009.

\subsection{Factors That Aid in the Decision Regarding Product Customization}

Product customization involves the changes made to the existing product in order to meet the conditions or expectations of the local market (KOTLER; ARMSTRONG, 2003). Chart 2 presents seven factors to be considered in the decision regarding product customization.

Certainly, the final decision in favor or against product customization depends on further analyses, as for example, the price obtained for the customized product, 
the costs involved, as well as the investment necessary for customization, among others. 
Chart 2 - Factors to decide between product standardization and product customization

\begin{tabular}{|c|c|c|c|}
\hline$\#$ & Factor & Decision criteria & Source \\
\hline 1 & $\begin{array}{c}\text { Physical } \\
\text { environment }\end{array}$ & $\begin{array}{l}\text { The country's physical conditions (weather, topography and natural resources) may demand product } \\
\text { customization. In countries where road conditions and fuel are of poor quality, there is a higher } \\
\text { demand to customize items as the engine and suspension. }\end{array}$ & $\begin{array}{l}\text { JAIN, 1993; HUMPHREY; } \\
\text { MEMEDOVIC, 2003; BASSI, } \\
\text { 1997; HILL, 2002; JOHANSSON, } \\
\text { 2006. }\end{array}$ \\
\hline 2 & $\begin{array}{l}\text { Legal } \\
\text { requirements }\end{array}$ & $\begin{array}{l}\text { Different countries have different laws regarding product standards, patents, tariffs and rates. } \\
\text { Countries differ, for example, in their regulations on safety, gas emissions and recycling. } \\
\text { Customizing products to meet these specifications represents a large impact on the cost and margin } \\
\text { of these products, and, at the same time, it is indispensable to operate in the country. }\end{array}$ & $\begin{array}{l}\text { JAIN, 1993; HUMPHREY; } \\
\text { MEMEDOVIC, 2003; BASSI, } \\
\text { 1997; CZINKOTA et al, } 2001 .\end{array}$ \\
\hline 3 & $\begin{array}{l}\text { Infrastructure } \\
\text { and } \\
\text { compatibility }\end{array}$ & $\begin{array}{l}\text { A country's availability, cost and development stage as regards transportation (road conditions and } \\
\text { maintenance), as well as energy voltage, may demand product customization. The system of } \\
\text { measurements also may demand customizing products. The difference between the metric system } \\
\text { and the British measurement system demands a costly conversion and harmonization process. }\end{array}$ & $\begin{array}{l}\text { JAIN, 1993; HUMPHREY; } \\
\text { MEMEDOVIC, 2003; BASSI, } \\
\text { 1997; HILL, 2002; JOHANSSON, } \\
\text { 2006. }\end{array}$ \\
\hline 4 & $\begin{array}{l}\text { Product life } \\
\text { cycle } \\
\text { development } \\
\text { level }\end{array}$ & $\begin{array}{l}\text { Different global markets - for a specific product - may present different development levels. These } \\
\text { differences can be explained through the concept of product life cycle: launch, growth, maturity and } \\
\text { decline. Thus, changes in the product are welcome in order to reach an appropriate product-market } \\
\text { balance. As an example, mature markets consider air bags for automobiles as a safety item, } \\
\text { whereas markets at the level of introduction do not offer this safety item for vehicles. }\end{array}$ & $\begin{array}{l}\text { JAIN, 1993; HUMPHREY; } \\
\text { MEMEDOVIC, 2003; CZINKOTA; } \\
\text { RONKAINEN, 2001. }\end{array}$ \\
\hline 5 & $\begin{array}{c}\text { Market } \\
\text { positioning }\end{array}$ & $\begin{array}{l}\text { Market conditions, namely, cultural differences, economic prosperity and consumer perceptions play } \\
\text { a role on the decision regarding product customization. Consumers in developing countries do not } \\
\text { have the financial resources to acquire products that consumers in developed countries may consider } \\
\text { to be essential ones. These products need to be duly modified to be sold to a larger market share in } \\
\text { the specific country, without lowering their quality and functionalities. This factor determines the } \\
\text { company's potential margins in the selected market. }\end{array}$ & JAIN, 1993. \\
\hline 6 & $\begin{array}{l}\text { Customers' } \\
\text { strategic } \\
\text { importance }\end{array}$ & $\begin{array}{l}\text { Different customers account for different margins in the company's portfolio. Global customers may } \\
\text { purchase significant amounts so as to use this to their advantage. These customers may also } \\
\text { demand that the company customize its product, as this reflects on their customer assistance } \\
\text { services in other countries. Example: Customizing products for Volkswagen in Brazil may result in } \\
\text { higher sales in Germany. }\end{array}$ & $\begin{array}{l}\text { CZINKOTA; RONKAINEN, 2001; } \\
\text { YIP, } 1999\end{array}$ \\
\hline 7 & $\begin{array}{l}\text { Suppliers' } \\
\text { strategic } \\
\text { importance }\end{array}$ & $\begin{array}{l}\text { Having a supplier base next to the manufacturing site is strategic. Yet, different environments, } \\
\text { countries and regions might entail having to accept rules, standards or materials that, on one hand, } \\
\text { would meet the needs of the product, but, on the other, would also result in altering projects or } \\
\text { substituting raw materials. These situations demand a certain level of product revalidation on the } \\
\text { part of engineering, i.e. in order to take advantage of having suppliers nearby, it is sometimes } \\
\text { necessary to implement changes in product engineering. }\end{array}$ & $\begin{array}{l}\text { JAIN, 1993; CZINKOTA et al, } \\
\text { 2001. }\end{array}$ \\
\hline
\end{tabular}

SOURCE: Adapted by the authors. 


\section{METHODOLOGY}

This exploratory and qualitative research has used the case study method, "[...] which is appropriate for the initial stages of research on a specific topic, or to offer a new perspective on a topic that has already been studied" (EISENHARDT, 1989, p. 548).

In the case of exploratory analyses, as the one proposed in this study, the aim is to understand the different aspects of the phenomenon, as well as its interactions. The sources of the primary data are usually qualitative in nature, thus, they need to be analyzed. The sample is usually small and not representative (SELLTIZ et al, 1975).

According to Yin (2005) the single and multiple case studies are variants of the same methodology structure: formulation of the research problem, definition of the unit case, determining the number of the cases, protocol development, data collection, data analysis and report preparation. It should be noted that the purpose of a case study is not to be representative of a population, but rather of the specific case under study (STAKE, 1994; SCANDURA; WILLIAMS, 2000).

For the purpose of this research, a single case study was carried out in a foreign multinational company from the auto parts sector. The sample for the study was taken from 'WAHLER do Brasil', a company with headquarters in Germany. The following steps were implemented in order to guide the field study:

i. Generate product customization scale (with the help of the engineering, sales and marketing departments).

ii. Identify the factors that influence the decisions regarding product customization (based on combining the above mentioned literature and the field study), and create a model.

iii. Analyze two customized products in the local market.

iv. Apply the model and verify the level of importance of each factor, in order to decide on the adjustments to be made in the product customization project.

Four interviews were held with three top managers at the company. Two interviews took place in the city of Piracicaba, at the Wahler facility, and two of them were held in São Paulo. Each interview took approximately two hours. Mr. Josué Monterossi is the General Manager, who has over 30 years of experience in the auto parts sector. Mr. Nelson Rovay holds the position of Commercial Director and has been with the company for 15 years. Mr. Karl Klumpp is the 
Industrial Director, and he has been with the company for five years. The top managers have been on their present jobs for over ten years.

Prior to the interviews, the questions were forwarded by e-mail to the interviewees, for them to be informed of the issues that would be addressed during the interviews. Additionally, the researcher gathered information from different sources, about the company and the products that would be the subject of the study.

At the same time, research was conducted with other types of documents, books, materials supplied by the company, publications, scientific articles, theses and dissertations, material taken from presentations on the subject, as well as visits to company sites on the internet.

Based on the definition of the overall purpose, as well as on the analysis of the theoretical foundations, Figure 1 presents the proposal for an empirical study, including the seven factors that influence the decisions regarding product customization: market positioning, customers' strategic importance, product lifecycle development, legal requirements, physical environment, infrastructure and compatibility, and suppliers' strategic importance.

Two products were selected for the empirical research, and they were analyzed in the context of their scale of importance as regards product customization. The scale was built on the basis of the theoretical foundation, as well as on the interviews held during the field study. The association between the scale of importance for product customization and the products being analyzed, namely, thermostatic valves, served as the basis for the decisions on product customization in the internationalization scenario. For the purpose of this case study, the internationalization scenario was applied to a specific country. 


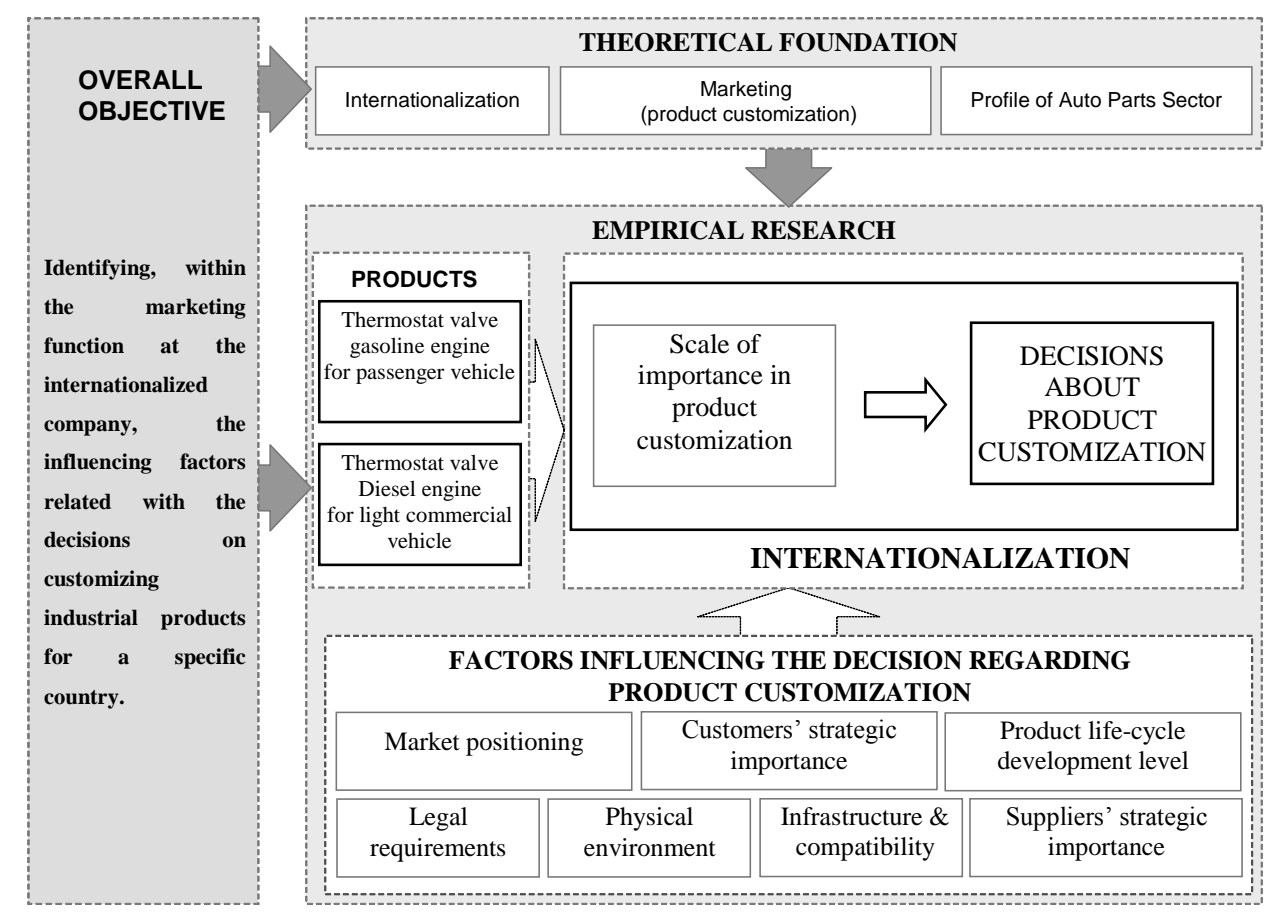

Figure 1 - Theoretical model for the research SOURCE: The authors.

\section{CASE STUDY: WAHLER}

Wahler is a German company, with subsidiaries in Brazil and in the United States, which develops and manufactures thermostatic valves and hoses for the automobile industry.

\subsection{Thermostats}

Thermostats are devices for the purpose of maintaining a specific system under constant temperature, and, in the case of this study, the system in question is the combustion engine. The function of the thermostat is to prevent the temperature of the engine from varying beyond pre-established limits.

With different requirements, as regards speed of reaction and flow, the different types of thermostats control the temperature inside the engine for the following: coolant, motor oil, transmission fluid, fuel, incoming air and compressed air.

For the purpose of this study, the main function of the thermostat is to control the temperature through the balance between the flow of coolant and the cooling system, which is made up of the radiator, the fan and the heater (WAHLER, 2009).

The thermostatic valve is located between the radiator and the water pump. The function of the valve is to control the temperature of the cooling water. Basically, after the engine is started, the cooling water is heated, which causes the wax element inside the valve to melt as it reaches a previously determined 
temperature, triggering the mechanisms to keep the engine within the ideal temperature range (Ibid.).

\section{ANALYSIS OF THE RESULTS}

For the purpose of this study, and within the Wahler product mix, the conventional wax-type thermostatic valve was selected, i.e. the main component in a thermostat. These thermostatic valves with conventional wax pellets are used for gasoline passenger vehicles, as well as for light commercial vehicles running on diesel fuel.

The starting point, in order to understand the choice of the thermostatic valves as the target of the present research, appears when one considers that the automobile company needs to manage, i.e. validate and store, engine components supplied by different sources. Thus, the automobile company itself should be in charge of assembling all the components on the engine assembly line.

In the case of the thermostatic valves that are the subject of the present study, Wahler has developed integrated products. This way, the automobile company purchases the final component, i.e. Wahler's functional warranty, and it is the latter that assembles the component directly onto the engine.

\subsection{Wahler's Criteria to Customize Thermostatic Valves}

Wahler is recognized in the local market as the leader in thermostatic valve technology, as well as the supplier of solutions for applications resulting from market needs and as defined by the customers, i.e. the thermostatic valve remains the same, but the customers' applications are different.

Thus, customizing thermostatic valves entails modifying the existing products, while maintaining their functional and assembly characteristics, in order to: reduce costs and investment needs, avoid patent infringement, and increase the standardization of the existing components for other applications.

One of the main challenges for the customization of thermostatic valves involves validating the functionalities that the product needs before and after it is customized. In other words, when a thermostatic valve is customized, at the end of the process, the valve must present the new functionalities that were requested, while maintaining its initial characteristics. 
Validating the functionalities takes up a large amount of the resources used for customization. Figure 2 illustrates the steps that are necessary for a thermostatic valve to be customized before it is manufactured.

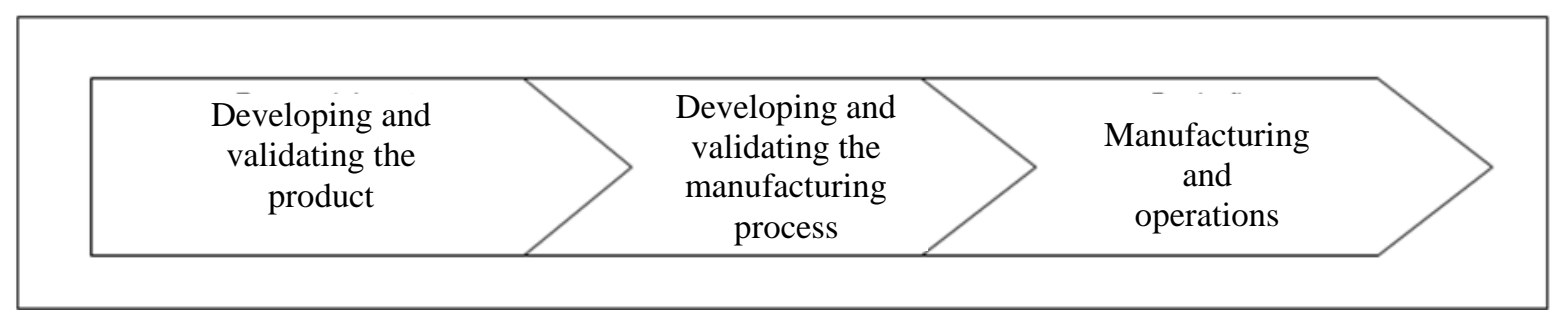

Figure 2 - Steps for the development of a thermostatic valve SOURCE: The authors.

i. Developing and validating the product. Several tests are necessary to guarantee that the customer's specifications have been met. This guarantees the following: being accurate, avoiding project errors at the manufacturing and operational stage, as well as carrying out validations, i.e. previously running simulations and analyses. Thus, by testing the capacity of the thermostatic valves and their adaptability to continuous use, the company guarantees success in this step, which takes an average of two years to be concluded (WAHLER, 2009).

ii. Developing and validating the manufacturing process. This step involves a thorough planning of the details for mass production of the thermostatic valves. On the average this process takes one year to be concluded, and it requires information about the machines and equipment used, as well as the production capacity within a specific timeline.

iii. Manufacturing and operations. Once the product functionalities and the manufacturing process have been defined and validated, the next step is the manufacturing of the thermostatic valve. It takes approximately three years to reach this stage.

The present study focuses on the first step in the development of a thermostatic valve, i.e. product development and validation. Chart 3 was prepared by the author, based on the information gathered from the interviews, and in collaboration with the General Manager and the Industrial Director of Wahler do Brasil. It covers the decision factors utilized for the customization of the thermostatic valves that are the subject of this study. 
The column on the left presents the seven factors for customization, ranked according to their relevance for the company (Wahler deciding factor), i.e. the most relevant one is the first one on the list, namely, market positioning. The second most relevant factor is listed underneath, and so forth, until the seventh most relevant one.

The horizontal line presents a customization scale ranging from 1 to 10 . These are subjective values, and they consider the level of importance granted by the company for the customization of the thermostatic valves in this study, during the development and validation step.

Thus, after extensive and thorough discussions with the interviewees, about each one of the seven factors mentioned above, it was possible to define the scale of importance in the decision to customize the thermostatic valves for Brazil.

A value of 1 means that the decision factor to customize the product has little relevance. The value equals 10 when the factor is highly relevant.

Chart 3 presents the summary of the results for the products considered in this research. Each one of the decision factors is analyzed below, as well as their importance for the customization of the thermostatic valves, which were identified as P1 (Gasoline engine for passenger vehicle) and P2 (Diesel engine for light commercial vehicle).

\section{Chart 3 - Decision factors utilized for the thermostatic valves in the present research}

\begin{tabular}{|c|c|c|c|c|c|c|c|c|c|c|}
\hline $\begin{array}{l}\text { P1. Gasoline engine for passenger } \\
\text { vehicle }\end{array}$ & & & ELU & $\begin{aligned} \mathrm{NCE} \\
\mathrm{Cl}\end{aligned}$ & $\begin{array}{l}\text { ON } \\
\text { STOI }\end{array}$ & $\mathrm{EC}$ & $\begin{array}{l}\text { ION } \\
\text { ON }\end{array}$ & $\mathrm{ABC}$ & & \\
\hline WAHLER DECISION FACTORS & 1 & ? & 3 & 1 & 5 & 6 & 7 & 8 & 0 & 10 \\
\hline 1. Market positioning & & & & & & & & & & $\mathbf{X}$ \\
\hline 2. Customers' strategic importance & & & & & & & & & $\mathbf{x}$ & \\
\hline 3. Product life-cycle development & & & & & & & & $\mathbf{x}$ & $\mathbf{x}$ & \\
\hline 4. Legal requirements & & & & & & & $\mathbf{X}$ & & & \\
\hline 5. Physical environment & & & & & & $\mathbf{x}$ & & & & \\
\hline 6. Infrastructure and compatibility & & & & & $\mathbf{x}$ & & & & & \\
\hline 7. Suppliers' strategic importance & & & & $\mathbf{x}$ & & & & & & \\
\hline
\end{tabular}

SOURCE: Prepared by the authors based on the interviews.

\subsubsection{Market Positioning}

The factor of market positioning, as presented in the section about theoretical foundations, means that the customers' perceptions in foreign countries will influence the decision regarding product customization. (JAIN, 1993).

In the case of the thermostatic valves this entails adopting the competitive strategy of differentiation, i.e. Wahler would invest heavily on company image, 
technology, $R \& D$, quality and market research, in order to create differentials for the customer (PORTER, 1980).

Thus, the products must be duly modified, to be sold to a larger share of the target market in the specific country, without lowering their quality and functionalities. Through this factor, the company's potential margins in the chosen market can be determined. (JAIN, 1993; DAY, 2001).

Wahler is well known among its customers for helping them meet their application needs, a fact which has afforded the company its position of leadership in the thermostatic valve market. In Brazil, the company accounts for $85 \%$ of the local thermostatic valve market.

Wahler's position in the market, therefore, is that of a company that supplies solutions - for customers with large production volumes - as well as products designed to facilitate manufacturing. These are characteristics typical of Porter's generic strategy (1980, p. 42), namely, cost leadership.

Yet, it should be highlighted that Porter's generic differentiation strategy (Ibid.) is only partially valid in the case of thermostatic valves. The characteristics of reputation as a leader in quality or technology, as well as in product engineering apply to the thermostatic valves in this study. Thus, we could say that there is a combination of Porter's generic strategies (1980) for the conditions presented in this case study.

As for the thermostatic valves involved in this research, if the customer does not reach a large enough scale in the local market, there might be scale at the global level. In countries with a large population and low income levels, the main objective is reducing costs. Production volumes in Brazil are lower than those in Europe, and there is not always a local demand for the products available in Europe.

Thus, Wahler Brazil reaches scale by exporting to other markets. Exports are $\mathrm{B} 2 \mathrm{~B}$, i.e. customers are prospected and, once the needs are analyzed, a solution is presented that includes a mock-up or life-size prototype. If the customer approves the proposal, a contract is signed and production will start in Brazil, to be then exported to the customer's destination. Customer prospecting takes an average of two years.

Consequently, when market positioning is considered as a customization factor for $\mathrm{B} 2 \mathrm{~B}$ customers, the need for customization is high (value attributed equals 
10), since this is one of the aspects that determines the company's potential margins in the local market.

\subsubsection{Customers' Strategic Importance}

Customers account for different margins in the company' portfolio. Global customers may have a significant purchasing volume, in order to use this advantage in their favor. These customers can demand product customization, as it will reflect on their customer assistance services in other countries. (YIP, 1999; CZINKOTA; RONKAINEN, 2001).

This customization factor is closely linked to the previous criterion. Additionally, the present criterion takes on an even larger dimension, as the local customers become global ones.

In the last ten years, the customers' strategic importance has become even more evident. A trend has been observed, among automobile manufacturers, to develop platforms for the production of only three types of engine around the world, i.e. engines for 1.0 to 1.6 vehicles, 2.0 to 2.5 vehicles, and 3.0 to 3.6 vehicles.

This means that few engine models and, therefore, few thermostatic valve types are available for export markets. Keegan and Green (1999) have stated that, overall, a product will be feasible for the international market if it does not undergo any other customization except that which is financially warranted by the expected sales volume, and, secondly, if the shipping costs to the target market are compatible with competitive price requirements.

Thus, the need for customization is high (value attributed equals 9) when the factor of the customers' strategic importance is taken into consideration. The benefits and arguments mentioned above warrant the investment in product customization. Among the benefits to be highlighted, the company is able to gain experience in the local market, which can be transferred to global markets, and consequently to global customers. Another benefit is to keep a steady relationship with an important customer.

\subsubsection{Product Life-cycle Development Level}

This factor may be defined as follows: different global markets present different development levels that can be explained through the concept of product lifecycle, which encompasses: launch, growth, maturity and decline. Changes in the product are therefore desirable, in order to reach an appropriate product-market 
match. (JAIN, 1993; HUMPHREY; MEMEDOVIC, 2003; CZINKOTA; RONKAINEN, 2001).

As an example, the heated thermostats or map-controlled thermostats include more technology than the conventional thermostats. Thus, a better control of the engine benefits the environment. (WAHLER, 2009). However, lack of appropriate legislation on emission controls has imposed limits on the use of this technology. As regards differentiation, if the item is not visible, it will probably not be included. On the contrary, if it is visible it might be included. The following are examples of items considered visible ones: airbags, leather seats or the color in fashion, at the time.

Humphrey and Memedovic (2003) have validated this argument by listing five main factors for product customization. Among them, we should highlight the one stating that, market demand varies in accordance with the average local salaries and income distribution. Consumers in countries with higher income levels tend to buy more sophisticated models with additional components, which are not found in the same models sold in underdeveloped countries.

A clear example of the higher final cost, for items that are considered as nonvisible ones in the vehicle, is the ABS brake. In Brazil, only $15 \%$ of the vehicles are equipped with this safety item, while in Europe, $100 \%$ of the vehicles include the item. In the US, this figure stands at 74\%. (O ESTADO DE S. PAULO, 2009). It is interesting to compare a visible item as the airbag, with a non-visible one as the ABS brake. The ABS system has an advantage over the airbag in that the former is considered an active safety device, i.e. it prevents accidents, while the airbag acts after the collision, by diminishing the impact and preventing major injuries.

It may be concluded that, as regards thermostatic valves, this customization factor is quite important, with an attributed value ranging between 8 and 9 . Thus, thermostatic valve customization is linked with the adoption of technologies included in the engine. In other words, if the engine is being developed for markets that depend on the involved costs to implement modern technology, the thermostatic valves are customized with the appropriate technology, to meet the demands of the target market. 


\subsubsection{Legal Requirements}

This customization factor considers the fact that countries have different laws about product standards, patents, tariffs and rates. In other words, countries differ in their regulations about safety, gas emissions and recycling. In order to meet these specifications, product customization will have an impact on the cost and margin of products, while, at the same time, it may be indispensable to operate in the country. (JAIN, 1993; HUMPHREY; MEMEDOVIC, 2003; BASSI, 1997; CZINKOTA et al, 2001).

Once the automobile company makes these product-component specifications available (product structure or bill of material), it is up to the manufacturer to develop the product or component, to meet the legal requirements defined by the company.

This customization criterion is important for the thermostatic valves, as regards the emission and control of pollutant exhaust gas that is produced by the engine, through the control of fluids: oil, fuel, air or water. In other words, an efficient thermostatic valve operation to control the temperature of the coolant flow means $1 \%$ to $2 \%$ savings in consumption, and approximately $2 \%$ to $3 \%$ better engine performance (WAHLER, 2009). Depending on the engine, these results may represent lower levels of pollutant gas emissions.

This customization factor bears a direct relationship with the criterion regarding the local market infrastructure. An example, not directly related with thermostatic valves, is the fuel production process in the local market.

It is useless to demand the control of gas emissions if the fuel does not meet the highest purity standard. The fuel presently used in Europe and in the US allows 50 ppm (particles per million) of sulfur. In Brazil, the fuel used in the local market contains 500 ppm of sulfur.

Thus, this factor may be summarized as follows: the lack of adequate legislation permits higher levels of gas emissions and noise, i.e. there is no need to use state-of-the-art technology for the thermostatic valves mentioned in this study, as opposed with the technology developed for the EGR valve, which is used in Europe and in the US.

Thus, as regards the thermostatic valves in this research, this customization factor is quite relevant, i.e. it must be related with the laws, rules and regulations that the local market defines as mandatory, and the value attributed 
to this factor equals 7. The costs resulting from the optional customizations will not be absorbed by the automobile companies.

\subsubsection{Physical Environment}

A country's physical conditions - weather, topography and natural resources may demand product customization. In countries where roads and fuel have lower quality, there is a need to customize items as vehicle suspension and engine. (JAIN, 1993; HUMPHREY; MEMEDOVIC, 2003; BASSI, 1997; HILL, 2002; JOHANSSON, 2006).

Aside from the weather, the customization factor related with the physical environment takes into consideration the following variables: surface configuration and topography of the local market. As regards materials specifications, the optional raw materials must be in compliance with the original production standards.

The customization factor is important in that, weather conditions, road conservation and maintenance or vehicle autonomy for long distances determine the conditions in which the engine and, consequently, the thermostatic valve will have to perform.

Thus, the physical conditions of the environment alter the operating temperature of the thermostatic valve. Examples: in Europe and in the US, there is a concern regarding the fast warm-up of the cabin. On the other hand, in Brazil, the highest concern is in regards to the physical conditions of the roads, i.e. topography-related efforts.

The thermostatic valve is not evaluated in isolation by the vehicle manufacturer. The power of the engine is assessed through tests of engine temperature, which are performed in the city of Teresina, in the state of Piauí. This region presents the highest temperatures in the country, and the end-of-life test for an engine is carried out in this region. Consequently, the thermostatic valve will also be analyzed under these conditions and, indirectly, it will be tested under the most strenuous conditions.

The present customization factor is, therefore, considered as having moderate importance and its value equals 6 . Since the thermostatic valves are not evaluated in isolation, customization will become necessary, based on the new engine resistance tests. These tests are applied by the vehicle manufacturers to the engines and, consequently, also to the valves. 


\subsubsection{Infrastructure and Compatibility}

A country's availability, costs and development stage, as regards transportation (road conditions and maintenance), and its energy voltage may demand product customization. The measurement system (Celsius or Fahrenheit temperatures) may also lead to product customization. The difference between the metric system (km/hr, kilometers per hour) and the British measurement system ( $\mathrm{mi} / \mathrm{hr}$, miles per hour) demands a costly conversion and harmonization process. (JAIN, 1993; HUMPHREY; MEMEDOVIC, 2003; BASSI, 1997; HILL, 2002; JOHANSSON, 2006; BROWN, 2006; CZINKOTA; RONKAINEN, 2001).

The factor regarding infrastructure and compatibility may or may not be related with the legal requirements of the local market. Should the local market bear high production volumes, then product customization becomes necessary, and, in the case of the present study, it involves customizing the thermostatic valves.

As regards the thermostatic valves themselves, this factor is of low importance, since the main issues involving infrastructure and compatibility are related with other engine components.

One aspect linked with compatibility is the scale used to measure the temperature variation of the expanding mass. In Brazil, temperatures are measured in degrees Celsius $\left({ }^{\circ} \mathrm{C}\right)$. If the thermostatic valves are exported to the US, they must obey the temperature scale in degrees Fahrenheit ( ${ }^{\circ} \mathrm{F}$ ).

Humphrey and Memedovic (2003) presented an example of what they have called driving conditions. In the underdeveloped countries, there is usually a situation of poor road maintenance and low quality fuel. In the case of Brazil, for example, the unfavorable road conditions demand customization of the suspension and shock absorption systems, i.e. they need to be more resistant than those in the US or Japan. Furthermore, the octane rating of Brazilian gasoline differs from the parameters utilized in Europe and in the US.

Thus, as regards thermostatic valves, this customization factor is of medium to low importance, and its attributed value equals 5. Customization will be necessary if the thermostatic valve is exported to markets where there is a difference between their measurement system and that of the market where the valve is manufactured. 


\subsubsection{Suppliers' Strategic Importance}

The last customization criterion states that having a supply base close to the manufacturing site is of strategic importance. Yet, different environments, countries and regions might entail having to accept rules, standards or materials which, on the one hand, would meet the needs of the product, but, on the other, would also result in altering projects or substituting raw materials. These situations demand a certain level of product revalidation on the part of the engineering department, i.e. in order to take advantage of having suppliers nearby (lower costs), it is sometimes necessary to implement changes in product engineering (JAIN, 1993; CZINKOTA et al, 2001).

The suppliers' strategic importance raises one important aspect as regards optional materials. Should they have the same technical specifications, for the manufacturing of the product, as the original ones, there is no problem in substituting the latter.

The following example may illustrate this statement. In Brazil, the PPA polymer is used to manufacture the thermostatic valves. Germany uses the PPS polymer, which has a higher cost and demands tool adjustment.

In order to describe the basic difference in the manufacturing process of thermostatic valves with PPA and PPS, the metaphoric image of two liquids will be used. Let us imagine there are two liquids, in two vessels. One of the vessels contains honey (metaphorically represented by the PPA). The other one holds water (metaphorically represented by the PPS).

Water (PPS) flows through any hole, gap or crack in the vessel. Honey (PPA) has a higher allowance for holes, gaps or cracks. The PPS has lower viscosity when the material melts.

Thus, as regards thermostatic valves, this customization factor is considered as having low importance, and its attributed value equals 4 . For the development and validation phase, the suppliers' strategic importance justifies the attributed value, since there is no need for large amounts of raw material.

\subsection{Summary of the Analysis}

Chart 4 presents an evolution of Chart 3, as new elements of comparison have been added. Thus, in column two, the factors have been ranked by their importance; column three presents the description of the Wahler decision criteria; column four introduces the summary of the analysis for the P1 
thermostatic valves (gasoline engine for passenger vehicle) and P2 (diesel engine for light commercial vehicle). Finally, in column five, there is a summary of the importance scale, as regards the influence factors, presented in this section. 


\section{Chart 4 - Summary of the factors that have an influence on the decisions regarding customization}

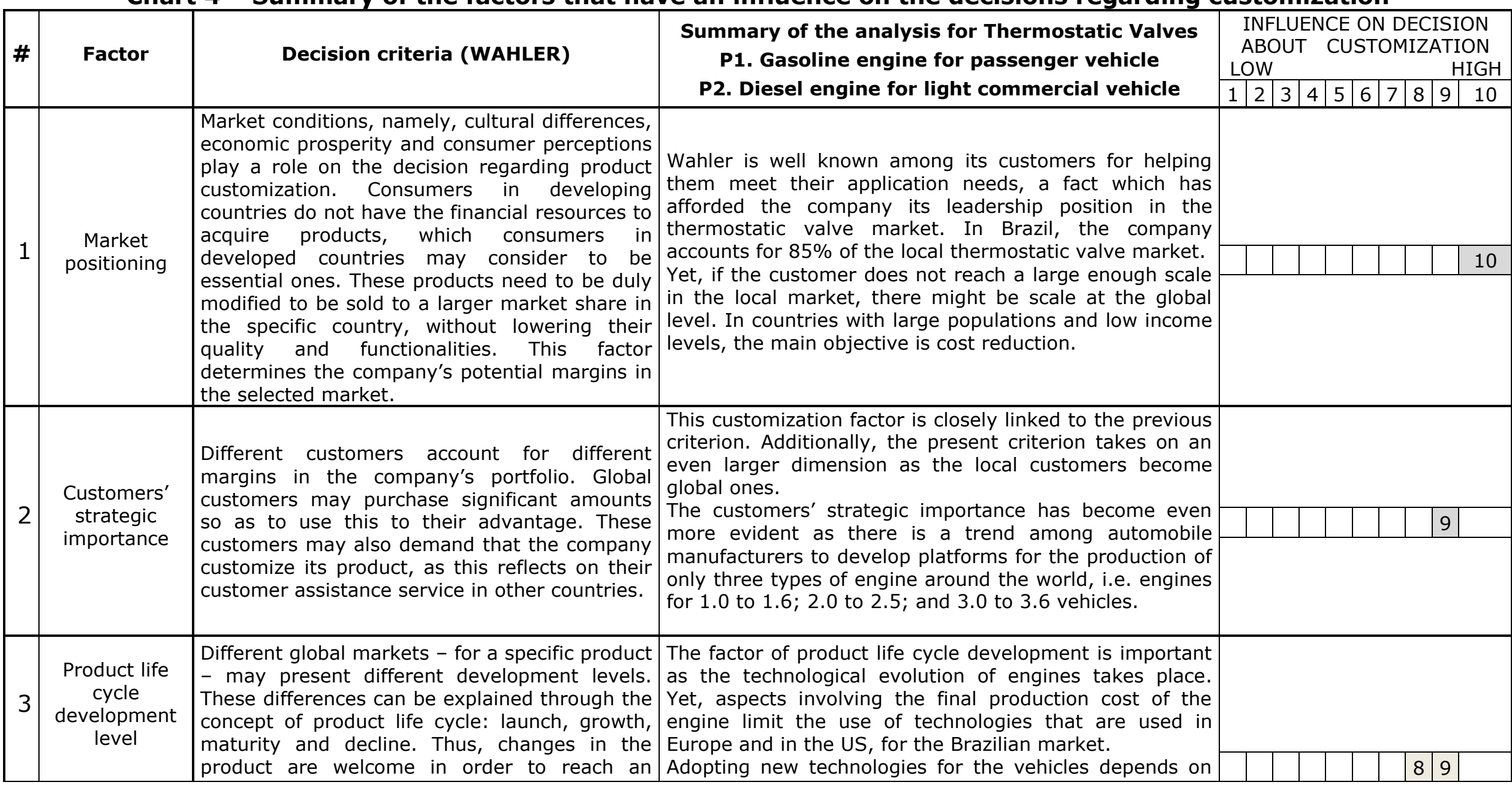




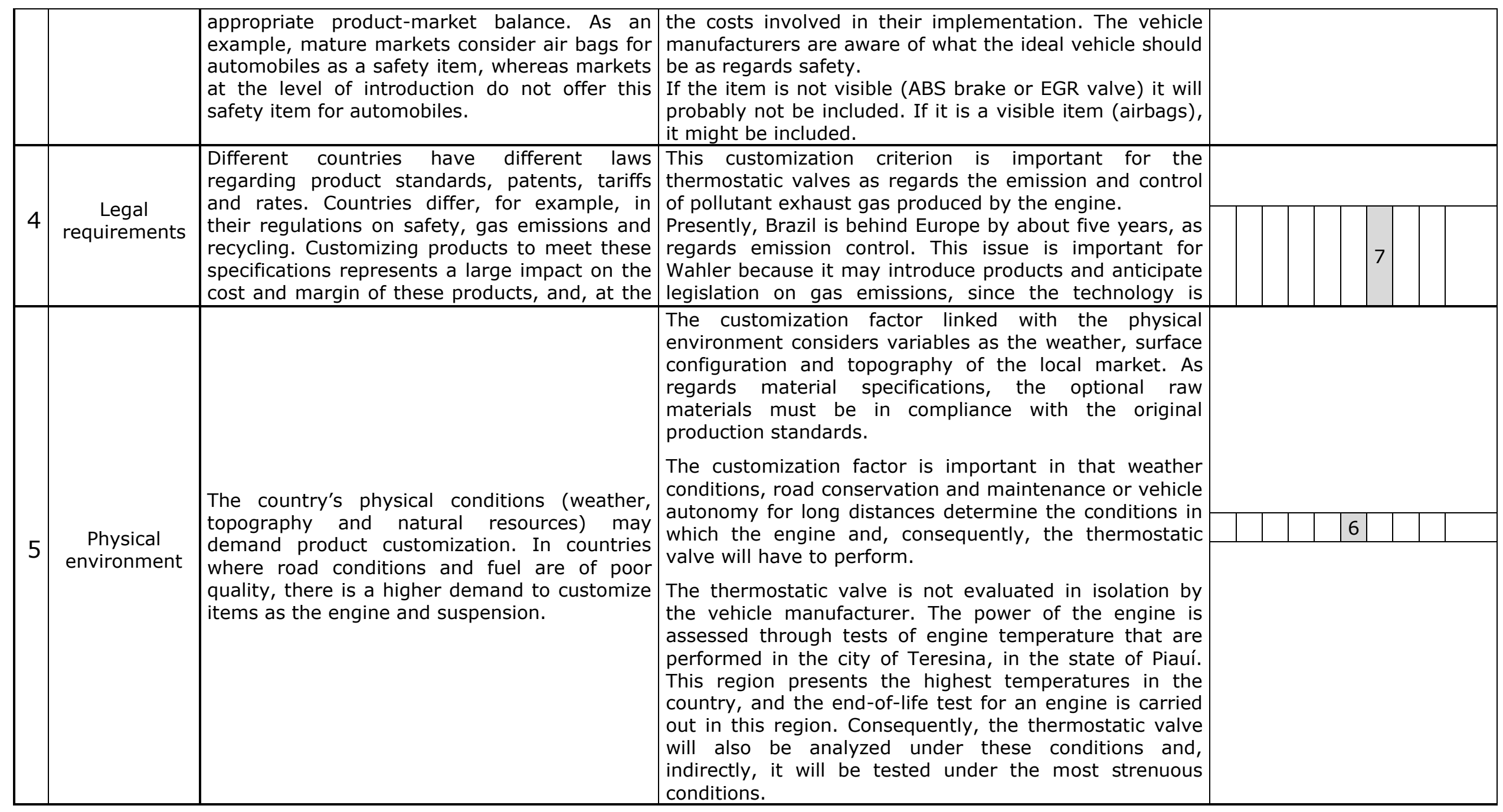




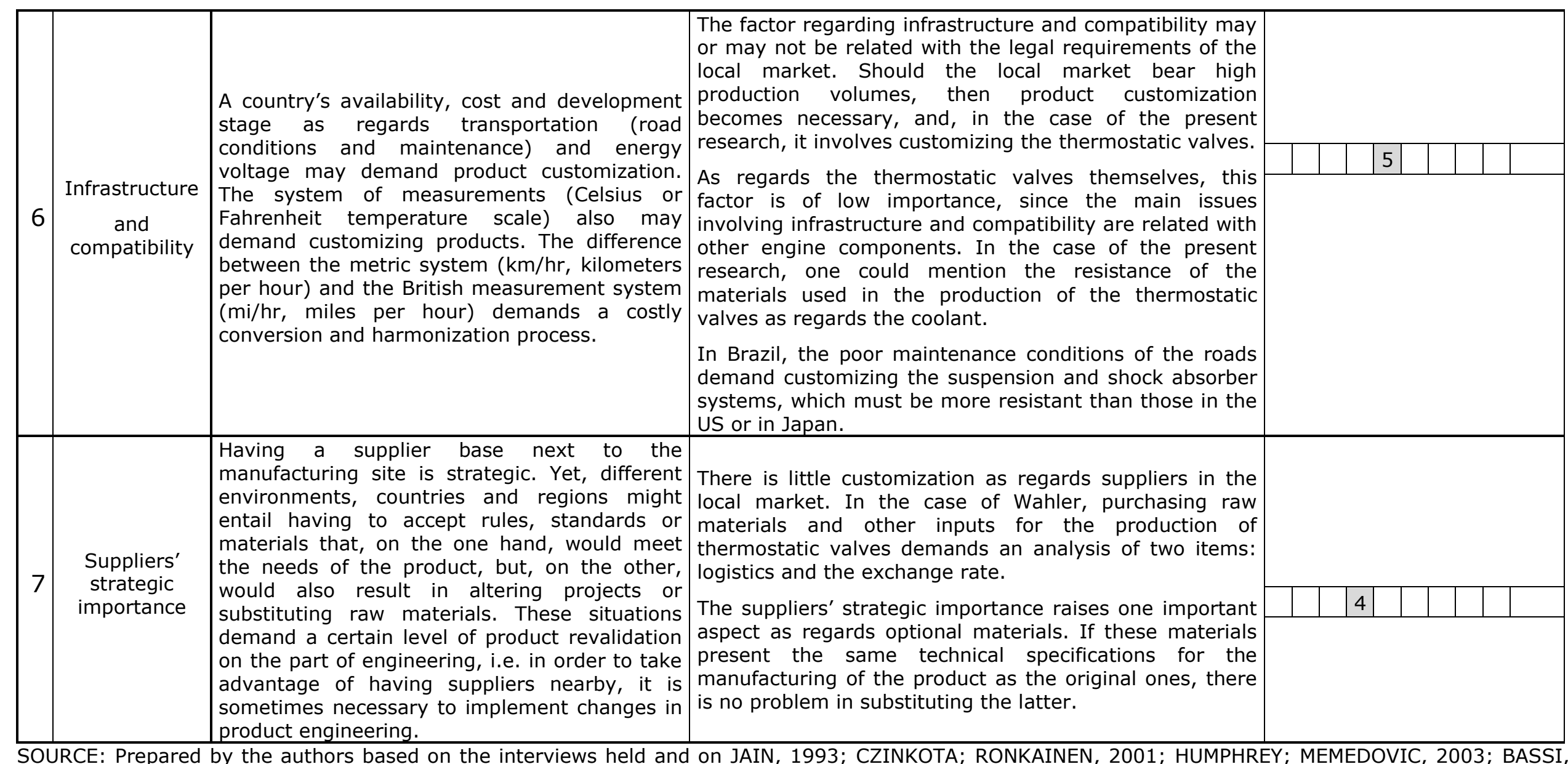

1997; CZINKOTA et al, 2001; HILL, 2002; JOHANSSON, 2006; YIP, 1999. 


\section{CONCLUSIONS AND FINAL CONSIDERATIONS}

The present research addresses a small part of the marketing mix, i.e. the customization of products in the B2B modality. As mentioned above, the literature on the subject is wide-ranging, yet, it is not conclusive as regards the factors that are essential for product customization. The present study focuses on identifying the factors that have an influence on the decision to customize, and applying this model to a multinational company in the automobile industry.

\subsection{Research Conclusions}

The starting point for the conclusions is based on the analysis of the factors influencing the decision to customize the products mentioned above. It remains clear that there are no simple formulas or generic solutions to customize products.

Customization at the lowest level, i.e. total standardization, means gaining scale and reducing costs. Yet, it cannot meet the customer's needs as regards technical specifications, which are decisive for the product to be accepted by the target market. Furthermore, it means the subsidiary will miss development opportunities.

Total customization, on the other hand, represents wide product acceptance on the part of the customers. This path, however, may render production unfeasible due to the high costs involved in meeting each customer's technical specifications. There are also losses in terms of synergy and chances to sell the product in new global markets.

There are endless possibilities in between these two ends of the product customization scale. Each situation warrants its own appropriate customization solution. As regards the present study, the solutions have been presented for the selected thermostatic valves.

The theoretical studies mentioned above (JAIN, 1993; HUMPHREY; MEMEDOVIC, 2003; BASSI, 1997; HILL, 2002; JOHANSSON, 2006; CZINKOTA; RONKAINEN, 2001; YIP, 1999) indicate that different factors have an influence on product customization, and they should be considered when companies internationalize their operations. The present work has analyzed only the seven factors that the author considers to be relevant. 
The first result from the analysis of the seven factors of influence shows that, as the company reaches new international markets, it faces the challenge of having to design strategies to capture economies of scale (PORTER, 1980), as well as synergies, without losing its capacity to meet the specific needs and characteristics of the markets where it is already operating. This entails adjusting the different factors that bear upon the company's marketing mix, so as to meet the competing and contradictory demands for product customization and standardization (LEVITT, 1983; DAY, 2001).

The auto parts industry offers an example of this adjustment process by showing that: specialized production, in local facilities, with technological innovation of products (PORTER, 1980; JAIN, 1993); the development of global customers (CZINKOTA; RONKAINEN, 2001); and production adjustments, in accordance with the life-cycle of the product in its target market (HUMPHREY; MEMEDOVIC, 2003) have become key elements in the decision to customize the thermostatic valves mentioned above.

The other three factors influencing the decision to customize products have been considered as having medium-level importance, since they are not totally under the company's control. These factors present features that are inherent to the political and physical environment of the target market.

In other words, should the company choose not to customize the following factors: legal requirements; physical environment; and, infrastructure and compatibility, the product will certainly not be accepted by the target market. These factors are linked with the above mentioned ones.

Finally, the factor of the suppliers' strategic importance presents a low level of importance because, in the case of thermostatic valves, there is no shortage of raw materials in the local market. Therefore, if the optional raw material for the production of these valves has the appropriate technical specifications, there is no need to seek global suppliers. The literature that was analyzed presents few references (JAIN, 1993; CZINKOTA et al, 2001) that resemble the concept related with this factor.

A final aspect, as regards the factor of the supplier's strategic importance, is that the relationship between Wahler and the automobile companies does not follow the same trend as the relationship between Wahler and its suppliers. The 
automobile companies tend to reduce the number of suppliers. In the case that was analyzed, the raw material suppliers for the production of thermostatic valves are eligible, as long as their technical specifications are compatible.

The case study has also shown that the influencing factors are interrelated. The first two factors should be highlighted, as the previous analysis of the results has indicated.

Thus, for the company to be a leader in the market of thermostatic valves, it needs to keep a strong relationship with its customers, as regards customizing solutions, whether to reduce exhaust emissions or to improve engine performance.

Furthermore, these two factors gain importance as the automobile companies make plans to reduce the types of engines that are offered in the global market. This reduction will have an impact on the suppliers of thermostatic valves, since they will also be fewer vis-à-vis the automobile companies.

Thus, the relationship between the factors of market positioning and customers' strategic importance becomes consolidated, as the company develops solutions for its customers, both for the local market as well as for the global one.

The key objective of the present study was to analyze the factors that influence the decisions on product customization. However, this focus does not preclude a wider understanding of the subject, based on theoretical foundations. It should be highlighted that the set of factors exerts a direct impact on the financial and strategic cost/benefit ratio for each decision towards customization.

A significant observation, different from the ones linked with the factors, has resulted from the continuum presented by Deresky (2003) in Figure 3. There is a relationship between the company's hierarchical model and the market positioning factor.

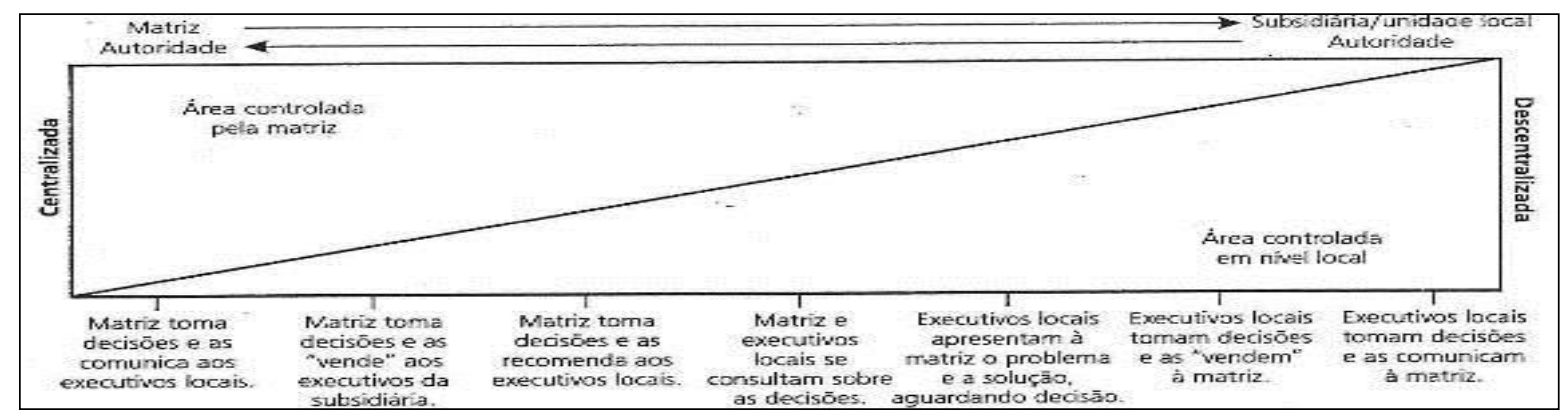




\section{Figure 3 - Site of decision making in an international company} SOURCE: DERESKY, 2003, p. 220.

The company analyzed in the present study is placed to the right of the continuum, on the point described as 'local managers make decisions and inform headquarters', since the company customizes its thermostatic valves and is the leader in the local market. The company moves towards the left of the continuum, to the point described as 'managers present the issue and the solution to headquarters and await a decision', in those cases in which customization may generate the risk of a recall.

The present study aimed at analyzing the factors influencing the decision about product customization in a specific country, namely, the thermostatic valves produced by Wahler for its B2B customers in Brazil. In this regard, it should be noted that the literature is not conclusive about the factors that are key for this task. Thus, a suggestion is hereby presented to define factors that are relevant for the company in the auto parts industry. Yet, these factors do not present an interpretation that may be extended for further contexts. It should be highlighted that factors from conceptual framework influence directly total costs and benefits from customization, it means, the company will drive the final decision.

\subsection{Research Limitations}

As is true with other issues involving social studies, mainly in the administration area, the present one is conditioned by such factors as subjectivity, difficulty to communicate or quantify. Thus, the limitations of the present research may be grouped into the following categories.

First, studies in the area of social science are strongly dependant on the unforeseeable nature of human phenomena, as well as on the difficulty to quantify such phenomena. The company's decision to customize products depends on the characteristics of the industry, as well as on the relationship between the headquarters and its subsidiaries, among others. Thus, the experiences reported in the present study may not apply fully to all companies.

Furthermore, the researcher depends on the interviewees and their willingness to share their unbiased experience, i.e. express opinions and ideas that represent the company's viewpoint as a whole, rather than their own. Sometimes, 
collecting data means running against obstacles, as regards the information offered, which may be considered confidential and strategic in nature.

Secondly, if on the one hand, the methodological choices made for the purpose of the research match its objective, on the other, these choices also define limitations. For example, it is impossible to guarantee that the answers obtained from the field would be the same on another occasion. This means that, should the research be repeated, the results might be different.

Since the present research follows the case study model, the results obtained may not be widely applied to a larger group of companies. (SAMPIERI et al, 2006).

Third, there is the limitation imposed by the researcher's own bias, which influences the study through the choice of methodology and the analysis of results. Vidich and Lyman (2006, p. 49) summarize this research limitation as resulting from the values that are not unique to the researcher, but stem from his/her social and cultural background.

A fourth limitation is related with the analysis of the theoretical foundations. An effort was made to encompass all the areas involved, with special attention given to the main authors and the most recent sources. However, these areas still need to be more thoroughly and fully analyzed.

Finally, the present study is not intended to generalize the results obtained from the case study, but rather to contribute towards a better understanding of the issue, as well as to open up new opportunities for further studies.

\subsection{Suggestions for Further Studies}

New subjects might be proposed for further studies, to be made by the present authors or other researchers, in the area of product customization.

The same methodology could be applied in other B2B sectors, in order to compare the factors influencing the decisions to customize products and their effects on the local and global markets. A variation of the previous suggestion would be to apply the methodology for B2C products, in order to compare the influencing factors with the ones obtained from the present study. Furthermore, other research might include different elements of the product mix as, for 
example, branding in B2B products, and the elements of customization in the international scenario.

All of the above mentioned suggestions may represent opportunities for further studies, so that the concept of product customization can be improved.

\section{REFERENCES} Wiley.

AAKER, D.A.; DAY, G.S. (1990). Marketing research. $4^{\text {th }}$ ed. New York:

BASSI, E. (1997). Globalização de negócios: construindo estratégias competitivas. São Paulo: Cultura.

BROWN, K. (2006). Step by step: working on multicultural teams. MultiLingual Computing Inc. Sandpoint, ID: v. 17, n. 82, Dec.

CATEORA, P.R.; GRAHAM, J.L. (1999). International marketing. $10^{\text {th }}$ ed. [S.I.], McGraw-Hill.

CZINKOTA, M.R.; RONKAINEN, I.A. (2001). International marketing. $6^{\text {th }}$ ed. Orlando, FL: Harcourt College Publishers.

CZINKOTA, M.R. et al. (2001). Marketing: as melhores práticas. Porto Alegre: Bookman.

DAY, G.S. (2001). A empresa orientada para o mercado: Compreender, atrair e manter clientes valiosos. Porto Alegre: Bookman.

DERESKY, H. (2003). Administração global estratégica e interpessoal. Porto Alegre: Bookman.

DUNNING, J.H. (1994). Re-evaluating the benefits of foreign direct investment. Transnational Corporations; v. 3, n. 1, February, p. 23-52.

EISENHARDT, K.M. (1989). Building theories from case study research. Academy of Management Review, v. 14, n. 4, p. 532-550.

FERDOWS K. (1997). Made in the world: The global spread of production. Production and Operations Management. v. 6, n. 2, Summer.

GATI, A.M. (2009). Padronização versus customização e gestão de empresas globais. In: VASCONCELLOS, E. (Coordinator). Gerenciamento da empresa global. São Paulo: Atlas (to be published).

HILL, C. W.L. (2002). International business: Competing in the global marketplace. New York: McGraw-Hill. 
HITT, M.A.; IRELAND, R.D.; HOSKISSON, R.E. (2008). Administração estratégica: competitividade e globalização. 2. ed. São Paulo: Cengage Learning.

HUMPHREY, J. MEMEDOVIC, O. (2003). The global automotive industry value chain: what prospects for upgrading by developing countries. Vienna: UNIDO.

JAIN, S.C. (1993). International marketing management. $4^{\text {th }}$ ed. Boston, MA: PWS-KENT Publishing Company.

JOHANSON, J.; VAHLNE, J. (1990). The mechanism of internationalization. International Marketing Review, vol. 7, n. 4, p. 1-24.

JOHANSSON, J.K. (2006). Global marketing: foreign entry, local marketing, \& global management. $4^{\text {th }}$ ed. New York: McGraw-Hill.

KEEGAN, W.J. (2005). Marketing global. 7. ed. São Paulo: Prentice Hall.

KEEGAN, W.J.; GREEN, M.C. (1999). Princípios de marketing global. São Paulo: Saraiva.

KEEGAN, W.J.; MORIARTY, S.E.; DUNCAN, T.R. (1995). Marketing. $2^{\text {nd }}$ ed. New Jersey: Prentice-Hall.

KOTLER, P.; ARMSTRONG, G. (2003). Princípios de marketing. 9. ed. São Paulo: Prentice Hall.

KOTLER, P.; KELLER, K.L. (2006). Administração de marketing. 12. ed. São Paulo: Prentice Hall.

LEVITT, T. (1983). The globalization of markets. Harvard Business Review, v. 61, p. 92-102, May-June.

O ESTADO de S. Paulo. São Paulo, year 130, n. 42157, 20/03/2009. Available at: <http://www.estadao.com.br/estadaodehoje/20090320>. Access on: $21 / 03 / 2009$.

PIPKIN, A. (2005). Marketing internacional: uma abordagem estratégica. 2. ed. São Paulo: Aduaneiras.

PORTER, M.E. (1980). Estratégia competitiva: técnicas para análise de indústrias e da concorrência. 2. ed. Rio de Janeiro: Elsevier.

SAMPIERI, R.H.; COLLADO, C.F.; LUCIO, P.B. (2006). Metodologia de pesquisa. 3. ed. São Paulo: McGraw-Hill.

SCANDURA, T.; WILLIAMS, E.A. (2000). Research methodology in management: Current practices, trends, and implications for future research, 
Academy of Management Journal, Mississippi State, v. 43, n. 6, p. 1248-1264, Dec.

SELLTIZ, C.; JAHODA, M.; DEUTSCH, M.; COOK, S. (1975). Métodos de pesquisa nas relações sociais. São Paulo: EPU.

STAKE, R.E. (1994). Case Studies. In: DENZIN, N.K.; LINCOLN, Y.S. Handbook of qualitative research. London: Sage Publications, p. 236-247.

VASCONCELLOS, E. (2008). Internacionalização, estratégia e estrutura. São Paulo: Atlas.

VASCONCELLOS, E.; MONTEROSSI, J.O.; BRUNO, M.A.C. (2007). Identification of technological threats and opportunities: Conceptual framework and application to an autoparts company. In: $16^{\text {th }}$ International Conference on Management of Technology, 2007, Miami: IAMOT - International Association for Management of Technology, p. 13-17, May.

VIDICH, A.J.; LYMAN, S.M. In: DENZIN, N.K.; LINCOLN, Y.S. and collaborators (2006). O planejamento da pesquisa qualitativa: teorias e abordagens. 2 ed. Porto Alegre: Bookman.

WAHLER (2009). Termostatos: Produtos para gerenciamento de temperatura. Catalog. Piracicaba, SP.

WAHLER (2008). Gustav Wahler GmbH. Available at: <http://www.wahler.de>. Access on: 20/11/2008.

YIN, R.K. (2005). Estudo de caso: planejamento e métodos. 3. ed. Porto Alegre: Bookman. Hall.

YIP, G.S. (1999). Total global strategy. Upper Saddle River, N]: Prentice 